\title{
A Simultaneous-Equation Model of Money Demand and Money Supply for Canada
}

\author{
Yu Hsing ${ }^{1^{*}}$, Abul M. M. Jamal ${ }^{2}$ \\ ${ }^{1}$ Department of Management \& Business Administration, Southeastern Louisiana University, Hammond, USA \\ ${ }^{2}$ Department of Marketing \& Supply Chain Management, College of Business, Southeastern Louisiana University, Hammond, USA \\ Email: ${ }^{*}$ hhsing@selu.edu
}

Received November 6, 2012; revised December 7, 2012; accepted January 8, 2013

\begin{abstract}
We estimate the money demand function and the money supply function for Canada simultaneously by the three-stage least squares method. The inflation gap and the output gap are incorporated in the money supply function. Real money demand is positively affected by real GDP and negatively associated with the Treasury bill rate and the nominal effective exchange rate. Real money supply is positively influenced by the Treasury bill rate and negatively impacted by the inflation gap and the output gap.
\end{abstract}

Keywords: Money Demand; Money Supply; Three-Stage Least Squares

\section{Introduction}

The demand for money has been examined extensively. Early seminal works include Chow (1966) [1], Saving (1971) [2], Goldfeld, Duesenberry and Poole (1973) [3], Laidler (1977) [4], Judd and Scadding (1982) [5], Gordon (1984) [6], Fair (1987) [7], Hafer and Jensen (1991) [8], and others. Studies for Canada and related countries include the focus on the stability [9-11], currency substitution [12-17], monetary policy [18], economic policies [19], nominal and real adjustments [20], simultaneity [21-23], etc.

To the authors' knowledge, most of recent studies employ the single-equation method in estimating the money demand function and assume that the money supply is exogenous or is not affected by the interest rate or other related variables. The assumption of an exogenous money supply may be inconsistent with the notion that a higher interest rate is likely to cause banks to make more loans and create more money supply and that central banks may adjust the money supply or the policy interest rate or both when the inflation gap or the output gap rises.

This paper attempts to examine the money demand function and the money supply function for Canada based on a simultaneous-equation model. The three-stage least squares (TSLS) method is employed in estimating the parameters. Therefore, estimated regression parameters are consistent, and simultaneity bias would not be present.

*Corresponding author.

\section{The Model}

Real money demand is postulated to be a function of the nominal interest rate, real GDP and the exchange rate:

$$
M^{d}=f(R, Y, \varepsilon),
$$

where $M^{d}=$ real money demand, $R=$ the nominal interest rate, $Y=$ real GDP, and $\varepsilon=$ the nominal effective exchange rate.

We expect that real money demand is negatively affected by the interest rate and positively influenced by real GDP. The sign of the nominal effective exchange rate may be positive or negative, depending upon whether the wealth effect or the substitution effect would dominate [12].

Real money supply may be expressed as

$$
M^{s}=h\left(R, \pi^{*}, Y^{*}\right)
$$

where $M^{s}=$ real money supply, $\pi^{*}=$ the inflation gap, and $Y^{*}=$ the output gap.

We expect that real money supply is positively associated with the interest rate and negatively impacted by the inflation gap and the output gap. A higher interest rate would provide more incentives for banks to increase loans and create more money supply. As the inflation gap or the output gap increases, a central bank is likely to pursue monetary tightening, leading to a decrease in the money supply.

In equilibrium, we have

$$
M^{d}=M^{s}
$$




\section{Empirical Results}

The data were collected from the International Financial Statistics published by the International Monetary Fund. M2 money is used to represent the quantity of money. The consumer price index is used to calculate real M2. The Canadian Treasury bill rate is selected as a representative interest rate. Real GDP is measured in billions at the 2005 price. The nominal effective exchange rate is chosen to represent the exchange rate. An increase means an appreciation of the Canadian dollar. The inflation gap is equal to the actual annualized inflation rate minus $2 \%$, which is the target inflation rate. The output gap is the deviation of actual real GDP from potential real GDP as a percent of potential real GDP. Potential real GDP is a trend value and estimated by the Hodrick-Prescott filtering process. Real M2, real GDP and the nominal exchange rate are measured in the log form whereas the Treasury bill rate [7], the inflation gap and the output gap are specified in the level form due to negative values before or after taking the $\log$ of these variables. The sample ranges from 1968.Q1 to 2011.Q4 with 176 observations. The data for M2 money are not available before 1968.Q1.

According to the ADF test, all the time series variables have unit roots in the level form and are stationary in first difference form. The ADF test on regression residuals indicates that the money demand function or the money supply function is cointegrated and has a long-term stable relationship.

Table 1 presents estimated parameters and other related statistics. In the money demand function, $99.2 \%$ of the variation in real money demand can be explained by the three right-hand side variables. All the coefficients are significant at the $1 \%$ or $5 \%$ level. Real money demand is negatively affected by the Treasury bill rate and the nominal effective exchange rate and positively influenced by real GDP. The negative significant coefficient of the nominal effective exchange rate suggests that the wealth effect dominates the substitution effect [12]. It appears that real money demand is more sensitive to real GDP than the Treasury bill rate or the nominal effective exchange rate.

In the estimated money supply function, $68.3 \%$ of the change in real money supply can be explained by the three right-hand side variables. All the coefficients are significant at the $1 \%$ level. Real money supply is positively associated with the Treasury bill rate and negatively affected by the inflation gap and the output gap. Note that real money supply is more sensitive to the Treasury bill rate than the inflation gap and the output gap. The larger coefficient for the inflation gap than the output gap in absolute values is consistent with the goal of inflation targeting adopted by the Bank of Canada.

Several other versions were considered. When the log of the Treasury bill rate is used, its negative coefficient in the money demand function is significant at the $1 \%$ level. Other results are similar. When the lagged dependent variable is added to the money demand function, the sign of the coefficient of the nominal effective exchange rate becomes positive and significant at the $5 \%$ level mainly due to a very high degree of multicollearity between the lagged dependent variable and real GDP. When the money supply function includes the interest rate and the

Table 1. Estimated money demand and money supply for Canada by the three-stage least squares (TSLS): The dependent variable is $\log ($ Real M2).

\begin{tabular}{ccc}
\hline & Coefficient & z-statistic \\
\hline Treasury bill rate & Money demand function: & -4.550 \\
$\log ($ Real GDP) & $-0.008 \mathrm{a}$ & 83.480 \\
$\log ($ Nominal effective exchange rate $)$ & $1.569 \mathrm{a}$ & -1.900 \\
Constant & $-0.063 \mathrm{~b}$ & -14.090 \\
$\bar{R}^{2}$ & -3.721 & 18.160 \\
& 0.992 & -8.280 \\
Treasury bill rate & Money supply function: & -3.680 \\
Inflation gap & $1.328 \mathrm{a}$ & \\
Output gap & $-1.080 \mathrm{a}$ & $-0.717 \mathrm{a}$ \\
$\bar{R}^{2}$ & 0.683 & 176 \\
Sample period & $1968 . \mathrm{Q} 1-2011 . \mathrm{Q} 4$ &
\end{tabular}

Notes: Letter a or $\mathrm{b}$ indicates that the coefficient is significant at the $1 \%$ or $5 \%$ level, respectively. 
inflation gap and omits the output gap, the negative coefficient of the inflation gap is significant at the $1 \%$ level, and other results are similar. If the CAN/USD exchange rate replaces the nominal effective exchange rate, the negative coefficient of the CAN/USD exchange rate is significant at the $10 \%$ level, suggesting that the use of the trade-weighted nominal effective exchange rate or the CAN/USD exchange rate may yield different outcomes. If the money demand function is estimated by the single-equation method, the negative sign of the coefficient of the nominal effective exchange rate is insignificant at the $10 \%$ level. Hence, the simultaneous-equation model combined with the three-stage least squares method would yield results that conforms better with economic theory. To save space, these results are presented in the appendix.

\section{Analysis}

As empirical results show, the money demand curve is downward sloping. A higher real GDP shifts the money demand curve upward, and vice versa. A higher nominal effective exchange rate shifts the money demand function downward, and vice versa.

The money supply curve is upward sloping. A higher inflation gap shifts the money supply curve leftward. Likewise, a higher output gap shifts the money supply curve leftward.

\section{Summary and Conclusions}

This paper has examined the money demand function and the money supply function for Canada simultaneously. The three-stage least squares method is used in estimating regression parameters. Major findings are that a lower Treasury bill rate, a higher real GDP or a depreciation of the Canadian dollar would increase real money demand and that a higher Treasury bill rate, a decreased inflation gap, or a decreased output gap would increase real money supply.

There are several policy implications. First, in estimating the money demand function, the money supply function should not be treated as exogenous and assumed to be unresponsive to the interest rate. Second, a change in the policy rate and other related interest rates in response to inflation targeting is expected to affect real money supply. Third, while the inflation gap is a major variable in the money supply function, the output gap is also significant in affecting monetary policy.

\section{Acknowledgements}

An earlier version of the paper was presented at the annual conference of the Southeastern Economic Association, November 2012, New Orleans, USA. The authors thanks valuable comments made by session participants.

\section{REFERENCES}

[1] G. C. Chow, "On the Long-Run and Short-Run Demand for Money," Journal of Political Economy, Vol. 74, No. 2, 1966, pp. 111-131. doi:10.1086/259130

[2] T. R. Saving, "Transactions Costs and the Demand for Money," American Economic Review, Vol. 61, No. 3, 1971, pp. 407-420.

[3] S. M. Goldfeld, J. Duesenberry and W. Poole, "The Demand for Money Revisited," Brookings Papers on Economic Activity, Vol. 1973, No. 3, 1973, pp. 577-646. doi: $10.2307 / 2534203$

[4] D. E. W. Laidler, "The Demand for Money: Theories, Evidence and Problems," 4th Edition, Addison Wesley, Boston, 1997.

[5] J. P. Judd and J. L. Scadding, "The Search for a Stable Money Demand Function: A Survey of the Post-1973 Literature," Journal of Economic Literature, Vol. 20, No. 3, 1982, pp. 993-1023.

[6] R. J. Gordon, "The Short-Run Demand for Money: A Reconsideration," Journal of Money, Credit \& Banking, Vol. 16, No. 4, 1984, pp. 403-434.

[7] R. C. Fair, "International Evidence on the Demand for Money," Review of Economics and Statistics, Vol. 69, No. 3, 1987, pp. 473-480. doi:10.2307/1925535

[8] R. W. Hafer and D. W. Jansen, "The Demand for Money in the United States: Evidence from Cointegration Tests," Journal of Money, Credit and Banking, Vol. 23, No, 2, 1991, pp. 155-168. doi:10.2307/1992774

[9] M. M. G. Fase, "In Search for Stability: An Empirical Appraisal of the Demand for Money in the G7 and EC Countries," De Economist, Vol. 142, No. 4, 1994, pp. 421-454. doi:10.1007/BF01384465

[10] D. L. Hoffman, R. H. Rasche and M. A. Tieslau, "The Stability of the Long-Run Money Demand in Five Industrial Countries," Journal of Monetary Economics, Vol. 35, No. 2, 1995, pp. 317-339. doi:10.1016/0304-3932(95)01189-U

[11] A. A. Haug and R. F. Lucas, "Long-Run Money Demand in Canada: In Search of Stability," Review of Economics \& Statistics, Vol. 78, No. 2, 1996, pp. 345-348. doi: $10.2307 / 2109938$

[12] S. Arango and M. I. Nadiri, "Demand for Money in Open Economies," Journal of Monetary Economics, Vol. 7, No. 1, 1981, pp. 69-83. doi:10.1016/0304-3932(81)90052-0

[13] M. Bahmani-Oskooee and M. Pourheydarian, "Exchange Rate Sensitivity of Demand for Money and Effectiveness of Fiscal and Monetary Policies. (Canada, Japan, US)," Applied Economics, Vol. 22, No. 7, 1990, pp. 917-925. doi:10.1080/00036849000000029

[14] J. H. Rogers, "The Currency Substitution Hypothesis and Relative Money Demand in Mexico and Canada," Journal of Money, Credit and Banking, Vol. 24, No. 3, 1992, pp. 300-318.

[15] S. K. Ghosh, "Currency Substitution and Demand for Money in Canada: Further Evidence," Journal of Macroeconomics, Vol. 11, No. 1, 1989, pp. 81-93.

doi:10.1016/0164-0704(89)90018-9 
[16] F.-L. Chu and J. Hou, "An Extension of Currency Substitution into the Near Monies Framework: A Case for Canada," Applied Economics, Vol. 30, No. 7, 1998, pp. 845851. doi:10.1080/000368498325273

[17] M. J. Pisani and D. W. Yoskowitz, "Does the Canadian Dollar Travel South? An Examination of Currency Substitution along the US-Canadian Border," American Journal of Business, Vol. 21, No. 2, 2006, pp. 61-70. doi:10.1108/19355181200600010

[18] F. Caramazza, D. Hostland and S. Poloz, "The Demand for Money and the Monetary Policy Process in Canada," Journal of Policy Modeling, Vol. 12, No. 2, 1990, pp. 387426. doi:10.1016/0161-8938(90)90040-L

[19] A. Kia, "Economic Policies and Demand for Money: Evidence from Canada," Applied Economics, Vol. 38, No. 12, 2006, pp. 1389-1407. doi: $10.1080 / 00036840600684879$
[20] K. L. Gupta and B. Moazzami, "Nominal vs Real Adjustment in Demand for Money Functions," Applied Economics, Vol. 22, No. 1, 1990, pp. 5-12. doi: $10.1080 / 00036849000000047$

[21] T. J. Courchene and A. K. Kelly, "Money Supply and Money Demand," Journal of Money, Credit \& Banking, Vol. 3, No. 2, 1971, pp. 219-244. doi: $10.2307 / 1991280$

[22] S. S. Poloz, "Simultaneity and the Demand for Money in Canada," The Canadian Journal of Economics/Revue Canadienne d'Economique, Vol. 13, No. 3, 1980, pp. 407-420. doi:10.2307/134701

[23] A. W Gregory and M. McAleer, "Simultaneity and the Demand for Money in Canada: Comments and Extensions," The Canadian Journal of Economics/Revue Canadienne d'Economique, Vol. 14, No. 3, 1981, pp. 488-496. doi:10.2307/134901 


\section{Appendix}

\begin{tabular}{|c|c|c|}
\hline & Coefficient & z-statistic \\
\hline \multicolumn{3}{|l|}{$\log \left(M^{l}\right)$} \\
\hline $\log (R)$ & -0.051 & -6.020 \\
\hline $\log (Y)$ & 1.507 & 68.280 \\
\hline $\log (\varepsilon)$ & -0.152 & -4.550 \\
\hline $\bar{R}^{2}$ & 0.994 & \\
\hline \multicolumn{3}{|l|}{$\log \left(M^{\Im}\right)$} \\
\hline $\log (R)$ & 4.414 & 20.250 \\
\hline$\pi^{*}$ & -0.576 & -6.060 \\
\hline$Y^{*}$ & -0.528 & -3.110 \\
\hline $\bar{R}^{2}$ & 0.761 & \\
\hline \multicolumn{3}{|l|}{$\log \left(M^{d}\right)$} \\
\hline$R$ & -0.002 & -5.580 \\
\hline $\log (Y)$ & 0.044 & 2.350 \\
\hline $\log (\varepsilon)$ & 0.012 & 2.190 \\
\hline $\log \left(M_{t-1}^{d}\right)$ & 0.968 & 80.900 \\
\hline $\bar{R}^{2}$ & 0.999 & \\
\hline \multicolumn{3}{|l|}{$\log \left(M^{\lessgtr}\right)$} \\
\hline$R$ & 1.338 & 17.89 \\
\hline$\pi^{*}$ & -1.115 & -2.45 \\
\hline$Y^{*}$ & -0.508 & -2.61 \\
\hline $\bar{R}^{2}$ & 0.671 & \\
\hline \multicolumn{3}{|l|}{$\log \left(M^{l}\right)$} \\
\hline$R$ & -0.005 & -2.790 \\
\hline $\log (Y)$ & 1.566 & 82.270 \\
\hline $\log (\varepsilon)$ & -0.087 & -2.650 \\
\hline $\bar{R}^{2}$ & 0.993 & \\
\hline \multicolumn{3}{|l|}{$\log \left(M^{5}\right)$} \\
\hline$R$ & 1.379 & 17.700 \\
\hline$\pi^{*}$ & -1.195 & -8.610 \\
\hline $\bar{R}^{2}$ & 0.648 & \\
\hline \multicolumn{3}{|l|}{$\log \left(M^{d}\right)$} \\
\hline$R$ & -0.010 & -5.480 \\
\hline $\log (Y)$ & 1.587 & 85.090 \\
\hline $\log (\mathrm{CAN} / \mathrm{USD})$ & -0.060 & -1.710 \\
\hline $\bar{R}^{2}$ & 0.990 & \\
\hline \multicolumn{3}{|l|}{$\log \left(M^{\Re}\right)$} \\
\hline$R$ & 1.260 & 17.570 \\
\hline$\pi^{*}$ & -0.963 & -7.590 \\
\hline$Y^{*}$ & -0.784 & -4.14 \\
\hline $\bar{R}^{2}$ & 0.695 & \\
\hline \multicolumn{3}{|l|}{$\log \left(M^{d}\right)$} \\
\hline$R$ & -0.005 & -2.994 \\
\hline $\log (Y)$ & 1.567 & 38.554 \\
\hline $\log (\varepsilon)$ & -0.083 & -1.057 \\
\hline $\bar{R}^{2}$ & 0.993 & \\
\hline
\end{tabular}

Notes: The constant term in the money demand function is included but not reported. CAN/USD is the units of the Canadian dollar per one US dollar. 